Creative Commons User License: CC BY-NC-ND

Abstracted by: EBSCOhost, Electronic Journals Service (EJS), Google Scholar, Journal Seek, Scientific Commons,

Food and Agricultural Organization (FAO), CABI and Scopus

http://eoi.citefactor.org/10.11226/v23i4
Journal of Agricultural Extension

Vol. 23 (4) October, 2019

ISSN(e): 24086851; ISSN(Print); 1119944X

http://journal.aesonnigeria.org

http://www.ajol.info/index.php/iae

Email: editorinchief@aesonnigeria.org

\title{
Non-farm Income Generating Activities of Rural Households in Abia State, Nigeria \\ https://dx.doi.org/10.4314/jae.v23i4.6
}

\author{
Nmeregini, Daniel Chinomso \\ Department of Rural Sociology and Extension, Michael Okpara University of Agriculture \\ Umudike, Abia state, Nigeria. \\ d.cnmeregini@yahoo.com Phone: 08131131206
}

\section{Nzeakor, Felix Chibueze.}

Department of Rural Sociology and Extension, Michael Okpara University of Agriculture Umudike, Abia state, Nigeria.

fcnzeakor@gmail.com Phone:08038310590

\section{Ekweanya, Ndidiamaka Martha}

Department of Rural Sociology and Extension, Michael Okpara University of Agriculture Umudike, Abia state, Nigeria.

amakahyginus7@gmail.com Phone: 08069603859

\section{Abstract}

The study analysed the non-farm activities of rural households in Abia State, Nigeria. Specifically, the study described the socio-economic characteristics of rural households, ascertained the various forms of non-farm income generating activities engaged by rural households, estimated the income earned from the non-farm activities and identified the constraints to participation in non-farm income generating activities among rural households. A multi-stage sampling procedure was used in selecting 160 respondents. Primary data used for the study were obtained through the use of a structured questionnaire and interview schedule. Frequency, percentage and means were used in analysing the data. Findings reveal that Most (55.0\%) of the respondents were engaged in nonfarm activities under service category. Trade and commerce non-farm category gave the highest income with the mean estimated annual income of A482,891.89. The major constraints to participation in non-farm income generating activities in the study area include increasing cost of fuel and other needed materials, lack or inadequate fund, bad state of the roads, and lack of credit facilities. The study recommended improvement in access to credit by rural households intending to venture into non-farm income generating activities, establishment of skills acquisition and entrepreneurial centres, encouraging of rural dwellers to venture into the more productive and lucrative non-farm activities, provision or improvement of basic infrastructures.

Keywords: Income, non-farm income generating activities, rural households. 
Creative Commons User License: CC BY-NC-ND

Abstracted by: EBSCOhost, Electronic Journals Service (EJS), Google Scholar, Journal Seek, Scientific Commons,

Food and Agricultural Organization (FAO), CABI and Scopus
Journal of Agricultural Extension

Vol. 23 (4) October, 2019

ISSN(e): 24086851; ISSN(Print); 1119944X

http://journal.aesonnigeria.org

http://www.ajol.info/index.php/iae

Email: editorinchief@aesonnigeria.org

http://eoi.citefactor.org/10.11226/v23i4

\section{Introduction}

Rural people have diversified their livelihood means and income earning portfolio across farm, non-farm and off-farm activities. Thus non-farm income generating activities have become an essential component of livelihood strategies among rural households (Agbarevo and Nmeregini, 2019). According to Ovwigho (2014), farmers particularly, the rural farm families usually engage in different non-farm income generating activities apparently to balance the shortfall of income due to the seasonality of primary agricultural production and create a continuous stream of income to cater for the various household needs.

Non-farm income generating activities include all economic activities in rural areas except agriculture, livestock, fishing and hunting. It includes all off-farming activities, processing, marketing, manufacturing, wage and causal local employment in the rural villages (Igwe, 2013). It encompasses all economic activities except the conventional crop production and livestock rearing (Agbarevo and Nmeregini, 2019). Rural non-farm income sector as described by Kazungu and Guuroh (2014) include: household and non-household manufacturing, trade, handicrafts, repairs, constructions, processing, transportation, communication, mining, and quarrying, as well as community and personal services in rural areas.

Rural non-farm income generating activities is considered as an essential component of livelihood strategies among rural households. The reasons for diversification to nonfarm activities include declining farm incomes and desire to insure against agricultural production risk. Household are pulled into the rural non-farm activities when returns from non-farm income activities are higher and less risky than in agriculture (lbekwe et al., 2013). According to Nishad and Tanjila (2015), most households in the rural communities engage in non-farm activities in order to enhance economic base.

Non-farm income generating activities are generally classified into two broad categories: 'high-labour-productivity that leads to high-income activities and lowlabour-productivity activities that serve only as residual source of income. The lowlabour-productivity activities are common among the poor. Such employment may be nevertheless very essential from a social welfare perspective. If agricultural employment is not an option for certain family members or sub-groups of rural population, then rural non-agricultural employment opportunities, even if they are not highly remunerative, can make a real difference, particularly for those households that do not possess farmlands (Madaki and Adefila, 2014).

It is worthy of note that having a universal classification of non-farm activities may not be easy as a result of the divergent classification of the types of non-farm income generating activities across geo-political locations and countries. In Abia state, the major non-farm activities engaged by the majority of people are transportation and trading. Other notable non-farm activities engaged by individuals in the State include food processing, restaurant/beer parlour, barbing saloon, teacher/clergy, craft making, dye and weave textile, soap making etc. (Obinna, 2014). Within the interior areas of the state, most of the people are involved in trading while very few persons are into 
Creative Commons User License: CC BY-NC-ND

Abstracted by: EBSCOhost, Electronic Journals Service (EJS), Google Scholar, Journal Seek, Scientific Commons,

Food and Agricultural Organization (FAO), CABI and Scopus
Journal of Agricultural Extension

Vol. 23 (4) October, 2019

ISSN(e): 24086851; ISSN(Print); 1119944X

http://journal.aesonnigeria.org

http://www.ajol.info/index.php/jae

Email: editorinchief@aesonnigeria.org

craft work. Most people in craft work are located within the semi-urban and urban areas of the State.

According to Ovwigho (2014), the types of rural non-farm income generating activities differs across geo-political locations and countries, which explains the apparent difficulties in the delineation of the effects of non-farm income generating activities on welfare of farmers. Furthermore, there is an increasing trend towards growth of village and rural industries, trade and transportation for providing alternative opportunities of employment as well as for meeting the rising need of the rural people (Nishad and Tanjila, 2015).

Moreover, rural areas enjoy a competitive advantage in the production of certain goods and provision of services as a result of the availability of natural resources, skills (in the case of rural craft-making) and cheap labour. Hence, the development of the non-farm sector may hitherto confer economic advantage due to protection from competition from outside markets and the inability of rural households to afford urban imports. Furthermore, the additional income generated from non-farm income can be used for farm investment (Sekumade and Osundare, 2014).

Apart from the economic advantages of rural non-farm employment, many social benefits could be accrued from them. The low productivity activities (such as craft production) create a trade-off between income and security; provide a buffer against agricultural failures in harsh years. Seasonality which causes peaks and troughs in labour utilization on the farm may lead to food insecurity due to the mismatch between farm income streams and continuous consumption requirements (Admiral, 2012). Moreover, non-farm income generating activities play a pivotal role in breaking the vicious cycle of poverty through its income smoothing effects on the rural population and consequently help to improve the food security status of rural dwellers.

Rural non-farm income generating activities are playing great roles in creating employment opportunities, consequently reducing poverty in rural areas (Nishad and Tanjila, 2015). It has been shown that rural non-farm activities have potential of absorbing a large number of would be youth migrants or youths who currently crowd the cities with under employment as they create immediate short-term or long-term employment opportunities which can be more easily tapped by young people. Thus, the non-farm sector has a great capacity for increasing rural employment, improving income distribution, contributing to economic growth, and poverty alleviation (Nishad and Tanjila, 2015). Rural non-farm activities play great role in alleviating or reducing income and non-income poverty of participating households by contributing a significant share to household income and enabling these households to purchase food and consumer goods, house building and repair, paying for medicine and health care, paying for education of the young as well as in investing in enhancing production activities such crop farming and livestock keeping (Jabo et al., 2014). Increasing the profitability and the array of non-farm activities improves livelihoods security and living conditions of the individuals. 
Creative Commons User License: CC BY-NC-ND

Abstracted by: EBSCOhost, Electronic Journals Service (EJS), Google Scholar, Journal Seek, Scientific Commons,

Food and Agricultural Organization (FAO), CABI and Scopus
Journal of Agricultural Extension

Vol. 23 (4) October, 2019

ISSN(e): 24086851; ISSN(Print); 1119944X

http://journal.aesonnigeria.org

http://www.ajol.info/index.php/jae

Email: editorinchief@aesonnigeria.org

The factors that motivate households to undertake non-farm activities are classified as "pull factors" and "push" factors. The "pull" factors include better returns in the nonfarm sector relative to the farm sector, while "push" factors include an inadequate farm output, resulting either from temporary events (e.g. drought) or longer-term problems (e.g. land constraints); an absence of or incomplete crop insurance and consumption credit markets (to use as ex post measures for harvest shortfalls); the risks of farming, which induce households to manage income and consumption uncertainties by diversifying and undertaking activities with returns that have a low or negative correlation with those of farming; an absence or failure of farm input markets or input credit markets, compelling households to pay for farm inputs with their own cash resources (Katega, 2013).

The factors that influence households' decision to participate in non-farm income generating activities have also been grouped into household characteristics, community characteristics, entry barriers and geographical Location. Household characteristics that influenced non-farm diversification behavior of the household include gender, age, education of the household head, and household endowments. The availability of infrastructural facilities such as roads, electricity and communication facilities have also been identified to influence farm households' decision to undertake non-farm employment (Shehu and Abubakar, 2015).

Katega (2013) shows that the main factors which deter rural households from participating in non-farm activities include lack of initial capital; limited number of family labour to serve in both farm and non-farm activities; inability to access financial credits and aversion of risks involved in investing in non-farm activities. The result further shows that non-farm activities such as welding, carpentry, tailoring and masonry require requisite skills, as such not all households or individuals can engage in such activities.

\section{Purpose of study}

Giving the intriguing role of non-farm income generating activities on the economic status and welfare of rural households, and the divergent factors impeding the participation of rural households in non-farm activities, it is pertinent to study the nonfarm activities in Abia state with view of determining the constraints to participation of the rural household in non-farm activities. Hence, study analysed the non-farm income generating activities of rural households in Abia State, Nigeria. Specifically, the study described the socio-economic characteristics of rural households in the study area, ascertained the various forms of non-farm income generating activities engaged by rural households in the study area, estimate the income earned from the non-farm activities and identified the constraints to participation in non-farm income generating activities among rural households in the study area.

\section{Methodology}

The study was conducted in Abia State. The State is one of States in the South Eastern part of Nigeria and one of the nine constituent States of the Niger Delta 
Creative Commons User License: CC BY-NC-ND

Abstracted by: EBSCOhost, Electronic Journals Service (EJS), Google Scholar, Journal Seek, Scientific Commons,

Food and Agricultural Organization (FAO), CABI and Scopus
Journal of Agricultural Extension

Vol. 23 (4) October, 2019

ISSN(e): 24086851; ISSN(Print); 1119944X

http://journal.aesonnigeria.org

http://www.ajol.info/index.php/jae

Email: editorinchief@aesonnigeria.org

region. Abia State lies between Longitude $04^{0} 45^{\prime}$ and $06^{0} 17^{\prime}$ North, and Latitude $07^{\circ} 00^{\prime}$ and $08^{\circ} 10^{\prime}$ East. The State is located within the forest belt of Nigeria, and the temperature ranges between $20^{\circ} \mathrm{C}$ and $36^{\circ} \mathrm{C}$. The population of Abia State was estimated at 3,727,347 in 2016 (NPC, 2017). Agriculture is the major occupation of the people, especially in the rural areas, involving over $70 \%$ of the population. A multistage sampling procedure was used in selecting the sample for the study. The first stage involved a purposive selection of four local government areas out of the seventeen local government areas in the state. The selected local government areas were Ikwuano, Umuahia North, Bende, and Isiukwuato. In the second stage, four autonomous communities were randomly selected from each of the selected local government areas. In the third stage, ten (10) respondents were randomly selected from each of the selected autonomous communities, thus making a total of 160 respondents, which constitute the sample size for the study. Primary data used for the study were obtained through the use of a structured open and closed end questionnaire and interview schedule. Frequency, percentage and means were used in analysing the data.

\section{Results and Discussion}

\section{Categories of Non-Farm Income Generating Activities}

Table 2 reveals the non-farm income generating activities engaged by the respondents. The non-farm income generating activities engaged by rural households in Abia State were categorized into trade/commerce, production, construction, service and others. The non-farm activities under trade/commerce category include petty trading, restaurant/beer parlour. Activities under production include tailoring, welding, soap making, and aluminium window work. Activities under construction include masonry/ bricklaying, carpentry, and electrical work. Activities under service category include barbing/hair dressing, photo/ video coverage, motor/ motor cycle mechanic, processing of produce, hired labour, teaching, decoration, catering and shoe making. While activities such as hunting, security/guard, animal treatment, timber operator, palm wine tapping, palm tree cutting, painting, dancing, plumbing were categorised under others.

Table 1 reveals that about $55.0 \%$ of the respondents were involved in non-farm activities under service category, while $46.88 \%$ of the respondents were involved in trade and commerce. However, $41.88 \%$ of the respondents were involved in petty trading. This is followed by transportation, tailoring and processing of produce $(18.75 \%),(11.88 \%)$ and $(7.50 \%)$ respectively. This result corroborates with Awoyemi, (2011) where $41.95 \%$ of the respondents were in service non-farm category and $15.34 \%$ in sales. The involvement of the rural household mostly in service non-farm category could be due to the fact that most of the non-farm activities under service non-farm category require little or no technical skill to undertake. Moreover, most of the service non-farm activities require little capital to start. Furthermore, most rural households lack the financial capacity to acquire the skill and obtain the facilities to venture into production and construction non-farm categories. The fact that a high proportion of the working population engaged primarily in service activities suggest 
Creative Commons User License: CC BY-NC-ND

Abstracted by: EBSCOhost, Electronic Journals Service (EJS), Google Scholar, Journal Seek, Scientific Commons,

Food and Agricultural Organization (FAO), CABI and Scopus

http://eoi.citefactor.org/10.11226/v23i4
Journal of Agricultural Extension

Vol. 23 (4) October, 2019

ISSN(e): 24086851; ISSN(Print); 1119944X

http://journal.aesonnigeria.org

http://www.ajol.info/index.php/iae

Email: editorinchief@aesonnigeria.org

that the dominant activities in rural Nigeria may belong to low-productivity, low income activities that may not lift people out of poverty (Awoyemi, 2011).

Table 1: Categories of non-farm activities

\begin{tabular}{lll}
\hline Categories of non-farm activities & Percentage & Rank \\
\hline Trade/ commerce & & $1^{\text {st }}$ \\
Petty trading & 41.88 & $8^{\text {th }}$ \\
Restaurant/ Beer parlour & 5.00 & \\
Sub-total & 46.88 & $3^{\text {rd }}$ \\
Production & & $12^{\text {th }}$ \\
Tailoring & 11.88 & $17^{\text {th }}$ \\
Welding & 2.50 & $15^{\text {th }}$ \\
Soap making & 1.25 & \\
Aluminium window work & 1.88 & $8^{\text {th }}$ \\
Sub-total & 17.50 & $12^{\text {th }}$ \\
Construction & & $10^{\text {th }}$ \\
Masonry/ brick laying & 5.00 & \\
Electrical /electronic work & 2.50 & \\
Carpentry & 4.38 & 2 th \\
Sub-total & 11.88 & $5^{\text {th }}$ \\
Service & & $20^{\text {th }}$ \\
Transportation & 18.75 & $6^{\text {th }}$ \\
Barbing/ hair dressing & 6.88 & $4^{\text {th }}$ \\
Photo/ Video coverage & 0.63 & $6^{\text {th }}$ \\
Motor/ Motor cycle mechanic & 6.25 & $11^{\text {th }}$ \\
Processing of produce & 7.50 & $12^{\text {th }}$ \\
Hired labour & 6.25 & $15^{\text {th }}$ \\
Teaching & 3.13 & $17^{\text {th }}$ \\
Decoration & 2.50 & \\
Catering & 1.88 & \\
Shoe making & 1.25 & \\
Sub-total & 55.00 & 10.00 \\
Others & & \\
Sub-total & & \\
\hline
\end{tabular}

Source: Field survey, 2016.

\section{Income Earned from Non-Farm Income Generating Activities}

Table 2 reveals that the non-farm activities under trade/commerce category gave the highest income with the mean estimated annual income of $\$ 482,891.89$, followed by

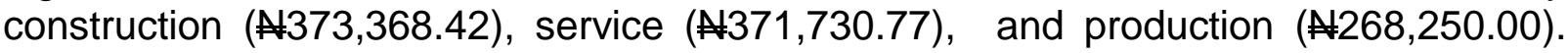
This implies that the greater proportions of the rural households are engaged low income yielding non-farm farm activities which may not lift them out of poverty. This justifies the reason why many rural households have remained poor despite their high involvement in non-farm income generating activities. 
Creative Commons User License: CC BY-NC-ND

Abstracted by: EBSCOhost, Electronic Journals Service (EJS), Google Scholar, Journal Seek, Scientific Commons,

Food and Agricultural Organization (FAO), CABI and Scopus

http://eoi.citefactor.org/10.11226/v23i4
Journal of Agricultural Extension

Vol. 23 (4) October, 2019

ISSN(e): 24086851; ISSN(Print); 1119944X

http://journal.aesonnigeria.org

http://www.ajol.info/index.php/jae

Email: editorinchief@aesonnigeria.org

\section{Table 2: Estimated annual income from non-farm income categories}

\begin{tabular}{lccc}
\hline $\begin{array}{l}\text { Non-farm } \\
\text { Category }\end{array}$ & $\begin{array}{c}\text { Mean annual } \\
\text { income (in N) }\end{array}$ & Std. deviation & Rank \\
\hline Trade \& & $482,891.89$ & 484133.34 & $1^{\text {st }}$ \\
commerce & & & \\
Construction & $373,368.42$ & $195,070.42$ & $2^{\text {nd }}$ \\
Service & $371,730.77$ & $306,012.46$ & $3^{\text {rd }}$ \\
Production & $268,250.00$ & $327,509.30$ & $4^{\text {th }}$ \\
Others & $258,687.50$ & $295,355.2$ & $5^{\text {th }}$ \\
Total & $524,987.42$ & $472,732.348$ & \\
\hline
\end{tabular}

Source: Field Survey, 2016.

\section{Constraints to Participation in Non-Farm Income Generating Activities}

Table 3 reveals the constraints to participation in non-farm income generating activities as identified by respondents.

Increasing cost of fuel and other needed materials ( $\bar{x}=3.52$ ), lack or inadequate fund $(\overline{\bar{x}}=3.25)$, bad state of the roads $(\bar{x}=2.98)$, lack of credit facilities $\bar{x}=2.88)$ were identified as the most notable constraints affecting the performance of non-farm income generating activities in Abia State. Other constraints identified included lack or unaffordable necessary machines and facilities $(\bar{x}=2.82)$, lack of electricity $\left(\begin{array}{l}\bar{x} \\ =\end{array}\right.$ 2.78 ), poor pricing by the public ( $\bar{x}=2.65)$, government policies and regulation ( $\bar{x}=$ 2.52). The finding is in agreement with the findings of Osondu et al. (2014) where inadequate capital to start up non-farm business $(43.3 \%)$ and Lack of access to credit $(35.0 \%)$ were identified as the foremost constraints to embarking in non-farm activity by rural women in Abia state. However, in the study of Michael (2015), lack of funds, lack or inadequacy of basic infrastructure, and lack of awareness/ training were identified as the most limiting factors affecting diversification into non-farm activities. Also, in a study conducted by Katega (2013), inadequate capital for running non-farm activities once started was determined as the most constraining factor affecting the performance of non-farm activities. 
Creative Commons User License: CC BY-NC-ND

Abstracted by: EBSCOhost, Electronic Journals Service (EJS), Google Scholar, Journal Seek, Scientific Commons,

Food and Agricultural Organization (FAO), CABI and Scopus

http://eoi.citefactor.org/10.11226/v23i4
Journal of Agricultural Extension

Vol. 23 (4) October, 2019

ISSN(e): 24086851; ISSN(Print); 1119944X

http://journal.aesonnigeria.org

http://www.ajol.info/index.php/iae

Email: editorinchief@aesonnigeria.org

Table 3: Constraints to participation in non-farm income generating activities

\begin{tabular}{lll}
\hline Constraints & Mean & Rank \\
\hline Increasing cost of fuel and other needed materials & $3.52^{*}$ & $1^{\text {st }}$ \\
Lack of/ inadequate fund & $3.25^{*}$ & $2^{\text {nd }}$ \\
Bad state of the roads & $2.98^{*}$ & $3^{\text {rd }}$ \\
Lack of credit facilities & $2.88^{*}$ & $4^{\text {th }}$ \\
Lack/ unaffordability of necessary machines and & $2.82^{*}$ & $5^{\text {th }}$ \\
facilities & $2.78^{*}$ & $6^{\text {th }}$ \\
Lack of electricity & $2.65^{*}$ & $7^{\text {th }}$ \\
Poor pricing by the public & $2.52^{*}$ & $8^{\text {th }}$ \\
Government policies and regulation & 2.48 & $9^{\text {th }}$ \\
Low patronage of craft by the public & 2.21 & $10^{\text {th }}$ \\
Health challenge & 1.85 & $11^{\text {th }}$ \\
Lack of creative ideas on better non-farm activities & 1.84 & $12^{\text {th }}$ \\
Lack of/ inadequacy of land & 1.82 & $13^{\text {th }}$ \\
Migration of youths to the urban areas & 1.77 & $14^{\text {th }}$ \\
Lack of water & 1.55 & $15^{\text {th }}$ \\
Education and skills required & 1.46 & $16^{\text {th }}$ \\
Age of household members & 1.36 & $17^{\text {th }}$ \\
Lack of required skills & 1.27 & $18^{\text {th }}$ \\
\hline Low technical know-how on the use of technologies & & \\
\hline
\end{tabular}

Source: Field survey, 2016.

\section{Conclusion and Recommendation}

Most of the rural households in the study area are engaged in non-farm income generating activities under service category. Hence, government and development actors should improve access to credit for through the establishment of micro-credit scheme and co-operative banks which will encourage savings and lend loans at low interest rates. They should establish skills acquisition and entrepreneurial centres where young adults could be trained on the skills and operations of different non-farm activities.

Encourage rural households to venture into the more productive and lucrative nonfarm activities like trade/ commerce and construction that will enable them to earn more income; and provide or improve basic infrastructure such as electricity, good access roads, portable drinking water and health facilities, among others. This will help to facilitate more involvement in non-farm activities and hence reduce poverty through promoting transfer of information, efficient markets, improving the working mobility of people, resources and outputs. 
Creative Commons User License: CC BY-NC-ND

Abstracted by: EBSCOhost, Electronic Journals Service (EJS), Google Scholar, Journal Seek, Scientific Commons,

Food and Agricultural Organization (FAO), CABI and Scopus

http://eoi.citefactor.org/10.11226/v23i4
Journal of Agricultural Extension

Vol. 23 (4) October, 2019

ISSN(e): 24086851; ISSN(Print); 1119944X

http://journal.aesonnigeria.org

http://www.ajol.info/index.php/iae

Email: editorinchief@aesonnigeria.org

\section{References}

Agbarevo, M.N.B. and Nmeregini, D.C (2019). Effect of non-farm income-generating activities on poverty reduction among rural households in Abia State, Nigeria. International Journal of Agriculture and Research, 2(1): 15 -25.

Ibekwe, U.C; Eze, C.C; Ohajianya, D.O; Orebiyi, J.S; Onyemauwa, C. S. and O.C. Korie (2013). Determinants of non-farm income among farm households in South East Nigeria. Researcher, 2(7): 49 - 52.

Igwe, P. A. (2013). Rural non-farm livelihood diversification and poverty reduction in Nigeria. PhD Dissertation, School of Management, University of Plymouth, U.K.

Jabo, M. S., Ismail, M. M., Shamsuddin, M. N. and Abdullah, A. M. (2014). The impact of nonfarm income generating activities on the food security status of rural households in Nigeria: International Journal of Agricultural Science and Veterinary Medicine, 2(4): $121-131$.

Katega, I. B. (2013). Rural non-farm activities and poverty alleviation in Tanzania: A case of selected villages in Chamwino and Bahi Districts in Dodoma region. Final Draft Report Presented at Policy Research for Development (REPOA) $18^{\text {th }}$ Annual Research Workshop held at the Kunduchi Beach Hotel, Dar es Salaam, Tanzania; April 3 - 4, 2013.

Kazungu, M. and Guuroh, T. R. (2014). Assessing the potential of non- -farm and off farm enterprises in spurring rural development in Uganda. International Journal of Agricultural Policy and Research, 2(5): 198 - 202.

Madaki J. U. and Adefila J. O. (2014). Contributions of rural non-farm economic activities to household income in Lere Area, Kaduna State of Nigeria. International Journal of Asian Social Science, 4(5): 654-663.

Nishad N. and Tanjila W. (2015). Contribution of rural non-farm activities in household income generation: A Study on Khulna Region. IOSR Journal of Humanities and Social Science (IOSR-JHSS), 20(10): 1-12.

Obinna, L. O. (2014). Assessing the benefits of non- farm and farm activities among rural dwellers in Ohafia and Umuahia Agricultural Zones of Abia State, Nigeria. Nigerian Journal of Agriculture, Food and Environment. 10(4):106-111.

Osondu, C. K., Obike, K. C., Ogbonna, S. (2014). Determinants of decision to non-farm entrepreneurship by women farmers in Ikwuano L.G.A of Abia State. European Journal of Agriculture and Forestry Research, 12 (4): 41-52.

Ovwigho, B. O, (2014). Factors influencing involvement in non-farm income generating activities among local farmers: The Case of Ughelli South Local Government Area of Delta State, Nigeria. Sustainable Agriculture Research, 3(1): 76 - 84.

Sekumade, A. B. and Osundare, F. O. (2014). Determinants and effect of livelihood diversification on farm households in Ekiti State, Nigeria. Journal of Economics and Sustainable Development, 5(5): 104 - 110. 
Creative Commons User License: CC BY-NC-ND

Abstracted by: EBSCOhost, Electronic Journals Service (EJS),

Google Scholar, Journal Seek, Scientific Commons,

Food and Agricultural Organization (FAO), CABI and Scopus

http://eoi.citefactor.org/10.11226/v23i4
Journal of Agricultural Extension

Vol. 23 (4) October, 2019

ISSN(e): 24086851; ISSN(Print); 1119944X

http://journal.aesonnigeria.org

http://www.ajol.info/index.php/iae

Email: editorinchief@aesonnigeria.org

Shehu A. and Abubakar N. (2015): Determinants of participation of farm households in nonfarm enterprise activities in rural Nigeria. International Journal of Economics, Commerce and Management United Kingdom; 3(6): 57 - 71. 